\title{
Człowiek na tle społeczno-gospodarczych uwarunkowań ochrony środowiska
}

\author{
Jacek Trzewik \\ Wydział Prawa, Prawa Kanonicznego i Administracji \\ Katolicki Uniwersytet Lubelski Jana Pawła II \\ I Katedra Prawa Cywilnego, Al. Racławickie 14, 20-950 Lublin, trzewik@kul.pl
}

\section{Streszczenie}

Na przestrzeni ostatnich lat znaczenia nabiera problematyka roli człowieka w jego relacjach ze środowiskiem. Wyrazem postępujących zmian jest chociażby stopniowe poszerzanie dorobku legislacyjnego przewidującego pewne uprawnienia podmiotowe jednostki, których realizacja ma istotne znaczenie dla osiągania celów stawianych ochronie środowiska. Na tym tle uzasadnione są także rozważania dotyczące gospodarczych oraz aksjologicznych uwarunkowań działań określanych mianem ochrony środowiska. Celem niniejszego opracowania jest wskazanie antropocentrycznych podstaw oraz aksjologicznych źródeł zachowań ujmowanych zbiorczo jako ochrona środowiska.

\section{Słowa kluczowe}

człowiek, ochrona środowiska, aksjologia, działalność gospodarcza

\section{Wprowadzenie}

Powszechne zainteresowanie sprawami ochrony środowiska nie pojawiło się pod wpływem nagłego impulsu, lecz wynika z faktu, iż człowiek od zawsze znacząco ingeruje w ciągłość środowiska. Dopiero jednak współcześnie zauważono i w odpowiednim stopniu doceniono problem nadwyrężenia kondycji środowiska. Wystarczy wspomnieć, że problemy ochrony środowiska zostały uznane przez społeczność międzynarodową za równie doniosłe w skali globalnej co kwestia zapewnienia światowego pokoju czy terroryzm (Łustacz 1975: 97). Mimo wszystko „troska człowieka o to, jaki wpływ jego działalność wywiera na naturalne środowisko, datuje się od niedawna.
A naukowe próby zmierzenia tego wpływu są jeszcze świeższe i z całą pewnością niewystarczające" (Boć i in. 2005: 176).

Współczesną działalność człowieka oraz przyjętą przez niego postawę w stosunku do środowiska coraz rzadziej postrzegać można jako korzystne dla jego ochrony. W konsekwencji, aktualnie środowisko nie zachowało zbyt wielu ze swoich pierwotnych cech. $\mathrm{Na}$ jego stan mają wpływ różnego rodzaju niebezpieczeństwa, w ogromnej większości wywołane przez człowieka i przy tym często nawet niezamierzone (Muszyńska-Kurnik 2003: 12). Ogólny stan światowego ekosystemu ulega zatem sukcesywnemu pogorszeniu. Coraz bardziej zauważalne stają się takie zjawiska czy procesy, które 
w znacznym stopniu odbiegają od norm uznawanych za nieszkodliwe dla samego środowiska, jak i człowieka. Istotne znaczenie ma również charakterystyczna internacjonalizacja zagrożeń ekologicznych. Procesy wpływające na degradację środowiska w jednym państwie wywołują negatywne konsekwencje także dla innych, przez co stają się integralnym elementem międzynarodowego środowiska. „Zanieczyszczenia nie znają bowiem granic państwowych i podlegają procesom eksternalizacji, tj. wyrzucania poza granice danego państwa" (Kukułka 1992: 117).

\section{Człowiek na tle gospodarczych uwarunkowań ochrony środowiska}

Na przestrzeni dziejów relacje człowieka i środowiska kształtowały się w dość różnorodny sposób. Wystarczy jednak stwierdzić, że początkowy lęk człowieka pierwotnego przed żywiołami przyrodniczymi, a następnie fascynacja pięknem środowiska naturalnego, przerodziły się w rabunkową gospodarkę zasobami naturalnymi i degradację środowiska aż do chwili obecnej, gdy człowiek musi zastanowić się nad koniecznością odnalezienia kompromisu między rozwojem gospodarczym a zachowaniem środowiska we właściwym stanie (Białocerkiewicz 2009: 62-63). Tym bardziej, że społeczeństwo egzystuje w środowisku, z którym pozostaje w bezpośrednim związku. Bez tego środowiska, bez utrzymania w nim podstawowych procesów, bez zachowania z nim stałego związku społeczeństwo nie mogłoby istnieć (Semkow 1974: 30-31).

Doniosłość problemu prawidłowego ukształtowania związków miedzy działalnością człowieka, w szczególności o charakterze gospodarczym, a środowiskiem, Sąd Najwyższy dostrzegł już pod koniec lat 6o-tych XX wieku. W jednym ze swoich orzeczeń zauważył, iż rozwój techniki i uprzemysłowienia kraju, jako jeden z elementów postępu, nie może przesłaniać równoczesnej konieczności zapewnienia obywatelom niezbędnego bezpieczeństwa i spokoju oraz może odbywać się jedynie w granicach nie stanowiących zagrożenia (wyrok SN z dnia 3 lipca 1969 r., sygn. II CR 208/69, „OSPiKA” 1971, z. 5, poz. 87, s. 199). Znamiennym jest przy tym fakt, iż to właśnie gwałtowny postęp techniczny, powodujący przewartościowanie dotychczasowej hierarchii dóbr tradycyjnie chronionych przez prawo, niejako wymusił wydanie orzeczenia traktującego o - wydawać by się mogło - dość oczywistej prawdzie (Sobczak 1975: 140).

Rola środowiska w procesach gospodarczych, aż do współczesnych czasów, nie była jednak przedmiotem zbytniego zainteresowania ekonomii, a to ze względu na fakt, iż zasoby naturalne dane zostały przez przyrodę we względnej dostatniości i nie zawierały w swym potencjale pracy rąk ludzkich (Górka i in. 2001: 113). Postrzeganie sił wytwórczych w oderwaniu od zasobów środowiska było przede wszystkim następstwem powszechnego poglądu, według którego dokonywano ich podziału na dobra użyteczne (jak np. zasoby mineralne) i tzw. dobra wolne, występujące w dość dużej obfitości i względnie łatwo dostępne. Wierzono przy tym w nieograniczoną zdolność środowiska do samoodnawiania się, a przez to także i w niewyczerpalność jego zasobów.

Wraz $\mathrm{z}$ intensywnym rozwojem produkcji materialnej oraz dokonywaną na niespotykaną dotąd skalę ilościową i jakościową ingerencją człowieka w środowisko, w teorii ekonomii pojawiły się pierwsze analizy uwzględniające w swym rachunku zasoby naturalne. Niestety, błędne rozumienie sił wytwórczych i istoty procesu reprodukcji środowiska utrwalały jedynie niedoskonały sposób jego postrzegania w procesie produkcji.

Stanowisko to uległo zasadniczej zmianie na początku lat 70. XX w. pod wpływem pierwszych, dość pesymistycznych publikacji naukowych dotyczących oceny potencjalnego rozwoju gospodarczego na tle ówczesnego stanu zasobów naturalnych, a pośród nich zwłaszcza Raportu Sithu U Thanta "Człowiek i jego środowisko” oraz I Raportu Klubu Rzymskiego Granice 
wzrostu (Meadows i in. 1973). Dostrzeżono w nich współzależność między stopniem rozwoju społeczno-gospodarczego a intensywnością zmian zachodzących w środowisku i wysokością nakładów ponoszonych na ten cel. Im wyższy bowiem stopień rozwoju gospodarczego, tym bardziej intensywne zmiany zachodzą w środowisku. Jest to wynikiem tego, że w procesach gospodarczych zużywane są przede wszystkim zasoby naturalne. Z drugiej strony środowisko jest zarówno źródłem surowców, jak i „odbiorcą" odpadów, ponadto wymusza także lokalizację i rozwój działalności gospodarczej na określonej jego przestrzeni (Machowski 2000: 141). Prowadzi to do konieczności podporządkowania całej gospodarki możliwościom, jakimi dysponuje środowisko (Ciechanowicz-McLean 2009: 112).

Podjęte zostały zatem starania w celu poszukiwaniu nowej, kompleksowej teorii ekonomii (teorii gospodarowania), uwzględniającej w swych założeniach także wymagania ochrony środowiska. Szczególną uwagę zwrócono na problem ograniczoności zasobów naturalnych, a także finalnie doceniono ich walory, takie jak niski stopień zanieczyszczenia, wartości estetyczne czy rekreacyjne.

Jedną z prób rozwiązania dylematów wynikających ze stosunku polityki gospodarczej do środowiska był zegizm. Ten neologizm, utworzony od angielskich słów zero growth cieszył jednak dość krótkotrwałą popularnością, gdyż dostrzeżono wszystkie jego niedoskonałości, w porównaniu z nie dość wysokimi walorami praktycznymi. Zakładał on bowiem „wzrost zerowy”, a więc konieczność powstrzymania lub znacznego ograniczenia wzrostu gospodarczego, stanowiącego zagrożenie dla człowieka i zmierzającego do zagłady środowiska (Wejroch 1972: 33-45).

Zaznaczyć należy, iż tworzenie nowego ujęcia stosunków między polityką gospodarczą a ochroną środowiska nie jest zadaniem łatwym i wymaga rozwiązania dość ważnych problemów. Podstawowa trudność tkwi w tym, że w klasycznym ujęciu ekonomii, środowisko w swojej pierwotnej formie nie ma typowej „wartości”, a przeważnie niezmiernie trudno jest je wycenić. Stąd w odróżnieniu od innych rodzajów produkcji zasoby naturalne nie podlegają ocenie w kategoriach pieniężnych, lecz w jednostkach naturalnych, co z kolei utrudnia (a wręcz uniemożliwia) ustalenie faktycznej ich wartości dla gospodarki narodowej (Dominik i in. 1988: 97-98). Ponadto, prowadzenie działalności gospodarczej z wykorzystaniem zasobów naturalnych w znaczny sposób wpływa na stan środowiska, co najmniej zmniejszając liczbę dostępnych zasobów, nierzadko jednak również powodując w nim wystąpienie poważnych szkód. Ekonomika środowiskowa wymusza zatem łączne rozwiązanie dwu podstawowych kwestii - określenia sposobu jak najefektywniejszej eksploatacji zasobów naturalnych niezbędnych do produkcji i konsumpcji oraz przeciwdziałania niepożądanym aspektom korzystania ze środowiska i likwidacji ewentualnych skutków degradacji środowiska.

$\mathrm{Na}$ tle załamania się koncepcji niezniszczalności i niewyczerpalności zasobów środowiska, szczęśliwie dostrzeżono niewystarczalność ogólnej troski o otaczające środowisko, czy w węższym ujęciu piękno przyrody. Podstawową kwestią była już nie tyle instrumentalnie pojmowana troska o poszczególne elementy natury, lecz zapewnienie ciągłości życia człowieka przez zachowanie i zapewnienie prawidłowego funkcjonowania całego „systemu ekologicznego" wraz z przynależnymi mu różnorodnymi formami życia. Fakt ten wymusił zmianę nastawienia człowieka, przede wszystkim na racjonalną, odpowiedzialną gospodarkę zasobami naturalnymi (Sobański 1998: 9).

Opracowanie nowych zasad regulujących wzajemne stosunki gospodarki i ochrony środowiska uwzględniać musiało w swoich założeniach także panujący system ekonomiczny świata, opierający się na podstawowym kryterium - zysku, osiąganym najczęściej właśnie kosztem środowiska. Pomijanie w rachunku ekonomicznym kosztów 
ekologicznych nie mogło mieć już racji bytu. Było to również o tyle trudne, że za wiodący miernik koniunktury gospodarczej uznaje się wysokość stopy wzrostu gospodarczego. Ten zaś oparty jest w głównej mierze na niezrównoważonych technologiach powodujących degradację środowiska i hołdujących niemal nieograniczonej eksploatacji bogactw naturalnych (Kozłowski 1997: 78). Istotnym problemem jest także to, że jednej strony postęp techniczny oraz poszerzanie produkcji nakierunkowane są na zaspokojenie potrzeb człowieka i zabezpieczenie możliwości jego wszechstronnego rozwoju decydując przez to o losie przyszłych pokoleń, z drugiej jednak tenże sam postęp techniczny w swoich licznych przejawach zaczyna bezpośrednio zagrażać biologicznemu środowisku człowieka. Tego rodzaju konflikty są bardzo złożone i tym trudniejsze do jednoznacznego rozwiązania. Jak bowiem trafnie ujął to W. Brzeziński „w każdym przecież przypadku chodzi o wyrzeczenie się i o poświęcenie czegoś: z teraźniejszości na rzecz przyszłości lub z przyszłości na rzecz teraźniejszości” (Brzeziński 1967: 16).

Powyższe rozważania w pełni uzasadniają zatem wniosek, iż ekonomiczne i społeczno-ekologiczne czynniki rozwoju świata powinny pozostawać we wzajemnym, ścisłym związku, dla dobra zarówno środowiska jak i samego człowieka. Teza ta jest odzwierciedleniem tzw. zasady retynizacji, stanowiącej dopełnienie zasady personalizmu. Natomiast łącznie z zasadą solidarności stanowią one podstawowe filary koncepcji zrównoważonego rozwoju (Juros 1995: 93), będącej współcześnie wyrazem kompromisu w relacjach człowiek - środowisko.

Koncepcja zrównoważonego rozwoju (sustainable development) jest powszechnie uznawana za wiodaccą zasadę zarówno międzynarodowej, jak i polskiej polityki ekologicznej. Pomimo posłużenia się tym terminem przez prawodawcę konstytucyjnego, w dalszym ciągu jest on źródłem rozważań terminologicznych i dyskusji nad adekwatnością przekładu na język polski angielskiego terminu. Po raz pierwszy została ona sformułowana w 1987 r. w będącym wynikiem prac Światowej Komisji do spraw Środowiska i Rozwoju (World Commission on Environment and Development) Raporcie „Nasza wspólna przyszłość” (Our Common Future), przedstawionym i przyjętym przez Zgromadzenie Ogólne Organizacji Narodów Zjednoczonych jesienią tegoż roku. Dokument ten, nazywany potocznie od nazwiska przewodniczącej pracom Komisji premier Norwegii Gro Harlem Brundtland po prostu Raportem Brundtland, wskazywał na koncepcję zrównoważonego rozwoju jako właściwą metodę harmonijnego, wieloaspektowego rozwoju społeczeństw, nie pozbawiającą równocześnie szans przyszłych generacji na zaspokajanie ich potrzeb związanych z rozwojem. Formułowanie szczegółowych założeń następowało sukcesywnie w toku prac społeczności międzynarodowych, znajdując swe odzwierciedlenie w nowopowstających dokumentach międzynarodowych czy sukcesywnie nowelizowanych dokumentach Unii Europejskiej. W ostatniej dekadzie XX w. nastąpiło już przyobleczenie zrównoważonego rozwoju w całościową koncepcję filozoficzno-prawną ochrony środowiska, traktując ją jako najbardziej zaawansowany i najskuteczniejszy sposób ochrony (Równy 200o: 58-71).

In genere, zrównoważony rozwój należy rozumieć jako konieczność prowadzenia polityki i realizowania działań w poszczególnych sektorach gospodarki oraz życia społecznego w taki sposób, by z jednej strony zachować aktualne zasoby i walory środowiska w stanie zapewniającym trwałe, nie doznające uszczerbku, możliwości korzystania z nich przez obecne jak i przyszłe pokolenia, z drugiej zaś by równocześnie zachować trwałość funkcjonowania procesów przyrodniczych i naturalnej różnorodności biologicznej (Przyborowska-Klimczak 2004: 25). Najprościej rzecz ujmując oznacza on zatem rozwój lub wzrost gospodarczy uwzględniający wymogi ekologiczne (Mazur-Wierzbicka 2006: 317).

Za podstawowe cele zrównoważonego rozwoju uznaje się powszechnie rozumiany 
jako zaspokojenie potrzeb ludzkich dobrobyt, międzypokoleniową i międzynarodową sprawiedliwość oraz bezpieczeństwo. Do celów drugiego stopnia, będących jednocześnie środkami realizacji zasadniczych celów tej koncepcji, zalicza się natomiast rozwój i zapewnienie trwałości funkcji ekologicznych (Lisicka 1998: 40). Przedmiotem zainteresowania zrównoważonego rozwoju są zarówno populacja ludzka, szeroko pojmowany świat roślinny, zwierzęcy, ekosystemy, zasoby naturalne, jak i najważniejsze wyzwania stojące przed światem: walka z ubóstwem, prawa człowieka, jego bezpieczeństwo czy zdrowie. Oprócz szerokiego zakresu treściowego zrównoważonego rozwoju, analizując to pojęcie podkreślić trzeba także jego złożony charakter. Zauważyć należy bowiem jego wymiar czasowy (określany mianem „trwały” czy „ciągły”) (Poskrobko 2005: 19-35), aspekt treściowy („zrównoważony, ekologicznie sprawiedliwy”) oraz dynamiczną perspektywę („rozwój")(Voinov 2008: 489) w odniesieniu do środowiska, w warunkach uporządkowanych działań ekonomicznych i politycznych, mających zapewnić bezpieczną przyszłość ludzkości (Juros 1998: 85). Dlatego też za istotę zrównoważonego rozwoju uznać można właśnie równorzędne traktowanie racji ekonomicznych, społecznych i ekologicznych, wymuszające tym samym konieczność integrowania zagadnień ochrony środowiska z politykami w poszczególnych dziedzinach gospodarki (Maśniak 2003: 21; Machowski 2003: 65).

Co więcej, bardzo istotnym założeniem tej zasady jest postrzeganie i charakterystyka rozwoju nie tylko jako stałego, samopodtrzymującego się procesu. Ze względu na konieczność promowania i podtrzymywania faktycznej odpowiedzialności za otoczenie, w które wpisana jest ludzka egzystencja, musi być on również ekologicznie sprawiedliwy (Juros 1995: 70-71). Ergo, uznając wprawdzie możliwość i faktyczną potrzebę korzystania z zasobów środowiska dla zapewnienia ciągłego rozwoju ludzkości, stawia ona kres traktowaniu tych zasobów jako dobra eksternistycznego, pomijanego w rachunku ekonomicznym, czy jako res nullius, pozostającego do swobodnej dyspozycji w rozwoju techniki i przemysłu. Wprowadza zamiast tego postulat nadrzędnej roli utrzymania równowagi przyrodniczej poprzez podporządkowanie pewnym podstawowym zasadom, jak zakaz wykorzystywania zasobów ponad ratę regeneracyjną lub ratę substytucji zasobów czy zakaz wprowadzania substancji czy energii do środowiska w ilości przekraczającej jego zdolności absorpcyjne (Juros 1995: 72-73). Dodatkowo, posługując się właściwie sformułowaną polityką ekologiczną, oddziałuje na gospodarkę, utrzymując na piedestale ochronę życia i zdrowia człowieka i zapewniając mu przez to biologiczne warunki dla życia. Innymi słowy zrównoważony rozwój jest współcześnie jednym z podstawowych paradygmatów prawa międzynarodowego, zarówno w kontekście ochrony praw człowieka, jak i środowiska (Krajewski 2010: 83).

W podobny sposób idea zrównoważonego rozwoju postrzegana jest przez polskiego ustawodawcę, co znalazło też odzwierciedlenie w ustawowej definicji tego pojęcia. Przez zrównoważony rozwój rozumie się taki rozwój społeczno-gospodarczy, w którym następuje proces integrowania działań politycznych, gospodarczych i społecznych, z zachowaniem równowagi przyrodniczej oraz trwałości podstawowych procesów przyrodniczych, w celu zagwarantowania możliwości zaspokajania podstawowych potrzeb poszczególnych społeczności lub obywateli zarówno współczesnego pokolenia, jak i przyszłych pokoleń (A: art. 3 pkt 50). Tak zakreśloną koncepcję zrównoważonego rozwoju wydaje się potwierdzać także polskie orzecznictwo, czego przykładem może być wyrok Trybunału Konstytucyjnego z dnia 6 czerwca 2006 r. (sygn. K 23/05, „OTK-A” 2006, nr 6, poz. 62), w uzasadnieniu którego odnaleźć można stwierdzenie, iż do zakresu treściowego zrównoważonego rozwoju należy także „troska o rozwój społeczny i cywilizacyjny, związany z koniecznością budowania stosownej infrastruktury, 
niezbędnej dla - uwzględniającego cywilizacyjne potrzeby - życia człowieka i poszczególnych wspólnot. Idea zrównoważonego rozwoju zawiera więc w sobie potrzebę uwzględnienia różnych wartości konstytucyjnych i stosownego ich wyważenia".

W doktrynie dostrzegalny jest jednak brak zgodności co do normatywnego charakteru zasady zrównoważonego rozwoju. W części prezentowanych stanowisk jest ona postrzegana jako zasada ustrojowa o normatywnym charakterze (Bukowski 2009: 463), w innych podkreśla się jej polityczne znaczenie (Lisicka i in. 1999: 255; Korzeniowski 2010: 297), w pozostałych zaś przyznaje rolę dyrektywy wykładni pełniącej rolę generalnej klauzuli odsyłającej (Rakoczy 2013: 22). Słusznym wydaje się jednak pogląd wskazujący, że zarówno zasady prawa, jak i generalne klauzule odsyłające stanowią egzemplifikację wartości zlokalizowanych na tzw. brzegu aksjologicznym, przez co nie należy przeceniać praktycznej doniosłości każdorazowego jednoznacznego binarnego sklasyfikowania konkretnego przepisu w kategoriach zasady lub klauzuli (Leszczyński et al. 2013: 90). W tym też kontekście legalne ujęcie zrównoważonego rozwoju w polskim systemie prawnym należy zatem uznać za swoisty konstrukt graniczny, który na podobieństwo cywilnoprawnych regulacji (chociażby zasad współżycia społecznego) uwzględniający w ramach zasady prawa cechy generalnej klauzuli odsyłającej.

Prawna regulacja zrównoważonego rozwoju w polskim systemie prawa uzupełniana i wspomagana jest przez szereg zasad o charakterze pomocniczym, które również odnoszą się do istotnych kwestii ochrony środowiska. Wskazać można chociażby na zasadę przezorności, prewencji, zanieczyszczający płaci, pomocniczości czy skuteczności ekologicznej i efektywności ekonomicznej. Zasady te, pomimo swej doniosłości i praktycznego stosowania przy podejmowaniu koniecznych działań z zakresu ochrony środowiska, uwikłane są w szereg dylematów o podłożu społecznym i gospodarczym (Rudnicki 2007: 212-215).
W doktrynie prawa ochrony środowiska koncepcja zrównoważonego rozwoju znalazła szerokie grono zwolenników. Coraz częściej zauważalne są jednak stanowiska wskazujące na niedostateczny jeszcze stopień wykorzystania tej zasady w praktyce oraz (mimo posłużenia się nią w licznych aktach prawnych) fakt jej prawnego niedookreślenia (Ciechanowicz-McLean 2009: 1819). Pojawiają się także sugestie, iż koncepcja ta nie jest ostateczną, doskonałą formą uregulowania stosunków między człowiekiem a środowiskiem, lecz może w wydatny sposób przyczynić się do znalezienia trzeciej drogi (oprócz zegizmu) rozwoju społecznogospodarczego w zgodzie ze środowiskiem (Górka 2011: 129).

\section{Człowiek na tle aksjologicznych uwarunkowań ochrony środowiska}

Współczesne problemy środowiska należy jednak postrzegać w szerokim ich ujęciu, poprzez pryzmat wielu złożonych zjawisk, procesów i zagadnień, dotyczących zarówno problemów ekonomicznych, finansowych, prawnych, administracyjnych, ustrojowych, technologicznych, jak i filozoficznych czy moralnych. Punktem wyjścia dla tego typu przemyśleń mogą być zatem zarówno kwestie ekonomii, finansów czy prawa, jak i też zagadnień z pogranicza aksjologii (Rudnicki 2007: 217).

Rozwój społeczeństwa jest silnie związany z jego kulturą. Jakkolwiek odnaleźć można wiele prób określenia tego pojęcia, w aspekcie materialnym przyjąć należy, że jest ona rozwojem człowieka wyrażającym się w podnoszeniu stopnia jego bytu społeczno-gospodarczego. Kultura jest tym, co między innymi odróżnia człowieka od pozostałych stworzeń żyjących w środowisku (Malinowski 1996: 36). Odzwierciedleniem tego rozwoju jest postęp, rozumiany jako stałe osiąganie coraz to wyższego poziomu społecznego i ekonomicznego, najczęściej kosztem stanu zasobów środowiska, którego ostatecznym celem jest człowiek, a konkretniej - jakość jego życia (Łabno 1987: 25-26). Nie dokonuje się on jednak w sposób stały 
czy równomierny. Wręcz przeciwnie, osiągnięcie wysokiego poziomu rozwoju w jednej dziedzinie nie pozostaje bez wpływu na inną, powodując tym samym powstanie dość niecodziennej sytuacji, gdzie „człowiek tworząc kulturę, jednocześnie ją niszczy” (Brzeziński 1971: 7).

Funkcjonowanie środowiska i człowieka jest zatem ściśle ze sobą powiązane. „Przyrody nie można pojąć bez społeczeństwa, ani też społeczeństwa bez otoczenia przyrody. Środowisko uległo uspołecznieniu; w następstwie samo zostało określone sposobem podejścia do niego. To kultura współkonstytuuje przyrodę (naturę)"(Juros 1998: 69). Wszelkie więc potencjalne postulaty w przedmiocie rozwiązania współczesnego kryzysu ekologicznego i każda racjonalna praktyka społeczna muszą zakładać socjokulturowe ujęcie środowiska.

Na szczególną uwagę zasługuje stanowisko J. Aleksandrowicza, który podejmując próbę zobrazowania stosunku człowieka do środowiska stwierdził, iż „kultura wyszła z przyrody i nosiła długo na sobie jej cechy, a potem zwróciła się przeciw niej, a kiedy pod nowoczesnym hasłem "ochrony» zawiera $\mathrm{z}$ nią znowu przymierze ... będzie nosić cechy nie kultury filisterskiej i barbarzyńskiej, nie dla źródła nowych kramarskich zysków rozwijanej, ale kultury prawdziwej wewnętrznej, kultury ducha i serca ... to hasło walki o najwyższe kulturalne dobra"(Aleksandrowicz 1975: 65).

Pojmowanie relacji człowieka i środowiska jest różne zależnie od poszczególnych nurtów filozoficznych, poglądów moralnych, religii czy koncepcji prawno-ustrojowych organizacji państwa. Ta problematyka jest rozwijana na wielu polach naukowych i w ramach różnorodnych dyscyplin nauk ekologicznych, w szczególności przez ekologię, sozologię, sozotechnikę, sozoekonomię, etykę środowiskową, bioetykę, ekofilozofię, ekoteologię czy politykę ekologiczną, na gruncie zaś prawa - prawo ochrony środowiska (Wrzosek 1999: 18; Kasprzak 2003: 43). Elementem łączącym wszystkie te nauki jest wartość osoby ludzkiej, będąca usprawiedliwieniem i podstawą prawa oraz dążenia człowieka do poszukiwania prawdy (Krajewski 2008: 69).

Wiele zatem innych, także pozaprawnych aspektów, determinuje społeczeństwo do podejmowania działań na rzecz zachowania środowiska w odpowiednim stanie. Ranga problemu wskazuje bowiem na konieczność jak najsilniejszego wspierania regulacji prawnych zasadami etycznymi, wszelkie bowiem działania człowieka o charakterze publicznym podlegają również ocenie moralnej (Łabno 1988: 261-264). Na zmiany w postrzeganiu relacji człowiek - przyroda niewątpliwy wpływ miały także odkrycia teoretyczne, jak i następstwa kulturowe towarzyszące sukcesom techniki (Życiński 1992: 22).

W filozoficznych rozważaniach dotyczących stosunku człowieka i chęci osiągania przez niego jak najwyższej jakości życia w relacji do środowiska, coraz częściej podkreślana jest konieczność wypracowania nowej podstawy socjokulturowej. Dominuje w tym zakresie pogląd, iż współczesne społeczeństwo, kształtując swój stosunek do środowiska, powinno odnaleźć nowy sposób życia i hołdować już założeniom „nowej zasad etyczno-społecznej, nowej, tj. bardziej adekwatnej i integralnej idei przewodniej w polityce ekologicznej. Bez nowego podejścia do kryzysu ekologicznego nie może być mowy o przeprowadzeniu koniecznej modernizacji ekologicznej społeczeństwa" (Juros 1998: 68; Menkes 1999: 23). Polegać ma ona przede wszystkim na zmianie postaw ludzkich, skupiając się na racjonalności podejmowanych działań oraz większej odpowiedzialności za własne życie, a także za życie społeczności świata, i to „nie tylko odpowiedzialności za ochronę i utrzymanie życia, ale również - w rozumieniu współczesnym - za jego odpowiednią jakość i właściwy standard" (Rudnicki 2005: 15).

Wskazane kryteria zachowań ludzkich uwzględnia w swoich ramach ekofilozofia. Jest to nauka o systemowym ujęciu problematyki filozoficznej środowiska społeczno-przyrodniczego. Jej podstawowe założenia 
wskazują, iż zdrowie i życie człowieka stanowią wartości nadrzędne, sam zaś człowiek jest istotą immanentną oraz transcendentną wobec przyrody. Przyjmuje ona założenia etyki odpowiedzialności za podstawową zasadę działalności człowieka, w wyniku czego ochrona warunków środowiska dokonuje się na zasadzie dostrzeżenia jego przyrodzonych wartości, niezależnie od subiektywnych odczuć człowieka, w wyniku czego staje się obowiązkiem człowieka (Gałkowski 1998: 260-261). Ponadto postrzega ona etykę, moralność i prawodawstwo ekologiczne jako istotne elementy edukacji ekologicznej, a przyrodę, kosmos i całe środowisko ujmuje jako dzieło stworzenia (Dołęga 1996: 8).

Idea ta czerpie wsparcie między innymi także w doktrynie nauki społecznej Kościoła katolickiego. Uznając etyczną zasadę solidarności za jedną z ważniejszych jej założeń, niemało miejsca poświęca kwestii ekologicznej. To filozoficzne podejście do pojmowania środowiska, wskazujące na moralne jego zakorzenienie, wywiera znaczaccy wpływ na świadomość i postępowanie społeczne.

Źródła podstawowych elementów koncepcji ekologicznie sprawiedliwego rozwoju odnaleźć można przede wszystkim w kościelnych dokumentach z zakresu filozofii chrześcijańskiej. Już papież Jan XXIII wskazywał na konieczność prowadzenia działalności gospodarczej w zgodzie z poczuciem odpowiedzialności (Jan XXIII 1981: 52). Podobnie papież Paweł VI, który stał na stanowisku, iż człowiek nie może godzić się na to, by jedynym bodźcem postępu gospodarczego był zysk, najwyższym prawem ekonomii była konkurencja, a prywatna własność środków produkcji prawem absolutnym, nie znającym żadnych ograniczeń i nie dostrzegającym powiązanych z nim zobowiązań o charakterze społecznym (Paweł VI 1981: 123).

Powiązanie postępu gospodarczego i kwestii ekologicznej z etyką dość często występowało również w encyklikach papieża Jana Pawła II. Już w encyklice Redemptor hominis zwrócił on uwagę na konieczność zmiany postawy człowieka względem przyrody.
Odnosząc się do chrześcijańskiej koncepcji panowania człowieka nad światem, za podstawę takiej zmiany uznał on prymat etyki nad techniką, osoby w stosunku do rzeczy oraz ducha nad materią. Postulował zatem przyjęcie przez człowieka raczej roli rozumnego pana i stróża, niż bezwzględnego eksploratora (Jan Paweł II 1981: 237-240).

Do kwestii ekologicznej odnosi się również inna encyklika papieża Jana Pawła II - Laborem exercens (Jan Paweł II 1996b: 138-139). Papież zalicza w niej korzystanie z dóbr natury do katalogu dóbr powszechnego używania, zauważając przy tym, że punktem styczności między człowiekiem a naturą jest właśnie eksploatacja tych zasobów. Do samych zaś dóbr natury włącza, oprócz dóbr konsumpcyjnych, także dobra natury rozumiane jako właściwy stan środowiska, w którym żyje człowiek (jak czyste powietrze, woda czy krajobraz). Dość istotnym problemem, na który wskazał papież w tej encyklice jest także fakt wykorzystywania ziemi i jej zasobów. Stwierdza on przy tym, że „polityka wolnorynkowa czerpie te zasoby ze względów komercjalnych, zaś według nauki Kościoła korzystanie z dóbr naturalnych jest wypełnieniem misji poddawania ziemi człowiekowi” (Dziadosz 200o: 113).

Zdaniem Jana Pawła II moralne aspekty rozwoju człowieka odnaleźć można przede wszystkim w nakazie poszanowania wszelkich bytów zgodnie z ich naturą. „Nie można bowiem bezkarnie używać różnego rodzaju bytów żyjących czy nieożywionych - składników naturalnych, roślin, zwierząt - w sposób dowolny, jedynie według własnych potrzeb gospodarczych" (Jan Paweł II 1996c: 355). Tak określony charakter rozwoju nakazuje również brać pod uwagę ograniczoność zasobów naturalnych, w dużej części należących do kategorii nieodnawialnych. Istotnym jest także przesłanie Papieża, który podkreśla, że „model rozwoju, który by nie szanował i nie popierał praw ludzkich, osobistych i społecznych, ekonomicznych i politycznych, łącznie z prawami narodów i ludów, nie byłby godny człowieka" (Jan Paweł II 1996c: 353). 
Papież Jan Paweł II w swoich pracach wspomina również o ludzkiej ekologii (łac. ecologia humana), przejawiającej się w tym, że człowiek postępuje racjonalnie, z poszanowaniem chrześcijańskich norm moralnych, wynikających z samej natury stworzenia (Jan Paweł II 1996a: 504-508). Zalicza się do nich zakaz bezkarnego wykorzystywania natury, uznanie wyczerpalności zasobów naturalnych, uznanie niewłaściwie pojętego postępu gospodarczego za przyczynę degradacji środowiska oraz fakt nieotrzymania przez człowieka od Boga władzy absolutnej nad stworzeniem (Górski 2013: 31).

Wśród autorów podejmujących trudny problem właściwego ujęcia ochrony środowiska w chrześcijańskiej filozofii, szczególną uwagę warto zwrócić na stanowisko wyrażane w pracach naukowych J. Życińskiego. Rozwijając chrześcijańską koncepcję roli człowieka na ziemi, zauważał on, iż to właśnie chęć poszukiwania prawdy o „ojczyźnie człowieka” - świecie przyrody, będącym szczególną postacią Bożego Wcielenia, stanowiła od zawsze inspirację dla największych osiągnięć w dziedzinie nauki, filozofii i sztuki. Jednakże spektakularne sukcesy nowych technologii sprawiły, iż obraz środowiska, który przetrwał ponad dwadzieścia stuleci, aktualnie począł się gwałtownie przemieniać w trakcie życia jednej tylko generacji. Podkreślał on, że „przyroda, która dla wielu generacji stanowiła dziedzinę dramatycznej walki o byt, ujawnia nam dziś ostrzej niż kiedykolwiek swe piękno [...] Tam, gdzie wcześniejsze generacje dostrzegały jedynie chaos nieskoordynowanych procesów, dla nas ujawnia się fascynująca rzeczywistość ukrytej głębi racjonalnych struktur" (Życiński 1992: 18o). Dlatego też, Jego zdaniem, ułaskawienie natury, rozumiane jako niezbędna zmiana w sposobie myślenia i postępowania człowieka, wymaga odejścia od instrumentalnej jej eksploatacji.

\section{Podsumowanie}

Przeprowadzone rozważania z zakresu społeczno-gospodarczych uwarunkowań ochrony środowiska ukazują antropocen- tryczne podstawy i aksjologiczne uzasadnienie aktywności podejmowanych w interesie środowiska, a tym samym w sposób jednoznaczny przesądzają o wzajemnym powiązaniu działań podejmowanych na rzecz ochrony środowiska z człowiekiem. W świetle przedstawionych rozważań należy przyjąć, że ostatecznym celem ochrony, z uwagi na przyrodzoną godność, jest każda osoba ludzka, a w szczególności jej zdrowie, życie i jakość życia.

Opierając się na przedstawionym powyżej ogólnym zarysie chrześcijańskich zasad moralnych odnoszących się do postępowania człowieka względem środowiska zauważyć można w szczególności wzajemne związki między etyką ekologiczną a chrześcijańską moralnością, łączących w sposób naturalny relacje człowieka i otaczającego go środowiska. Widoczne jest to zwłaszcza w przyjętej koncepcji sustainable development, opartej na założeniach antropologii aksjologicznej i normatywnej szerokich tradycji ekologicznych o chrześcijańskich korzeniach (Dziadosz 2000: 114).

Przeprowadzone rozważania skłaniają ponadto ku refleksji, że niezależnie od pobudek leżących u podstaw podejmowania działań na rzecz środowiska, czy to ze względu na wolę zachowania pierwotnego piękna środowiska, chęć ochrony zdrowia i życia człowieka, czy to z uwagi na potrzebę zachowania religijnej postawy względem natury, kluczową sprawą jest obecnie uznanie uzasadnionej aksjologicznie roli aktywności człowieka w działaniach prośrodowiskowych.

\section{Bibliografia}

Aleksandrowicz J., 1975, Wptyw zmian środowiska na zdrowie człowieka, w: L. Łustacz (red.), Prawo a ochrona środowiska, Wrocław - Warszawa Kraków - Gdańsk.

Białocerkiewicz J., 2009, Relacje człowieka ze środowiskiem naturalnym. Garść refleksji o konflikcie prawa i ekonomii, w: B. Mikołajczyk, J. Nowakowska-Małusecka (red.), Prawo międzynarodowe, europejskie i krajowe - granice i wspólne obszary. 
Księga jubileuszowa dedykowana Profesor Genowefie Grabowskiej, Katowice.

Boć J., Nowacki K., Samborska-Boć E., 2005, Ochrona środowiska, Wrocław-Kolonia.

Brzeziński W., 1967, Ochrona prawna czystości wód i powietrza atmosferycznego - zagadnienie humanizmu w prawie, Państwo i Prawo, nr 7.

Brzeziński W., 1971, Ochrona prawna biologicznego środowiska człowieka, Warszawa.

Bukowski Z., 2009, Zrównoważony rozwój w systemie prawa, Torun.

Bukowski Z., Czech E., Karpus K., Rakoczy B., (red.), 2013, Prawo ochrony środowiska. Komentarz, Warszawa.

Ciechanowicz-McLean J., 2009, Prawo i polityka ochrony środowiska, Warszawa.

Dołęga J. M., 1996, Miejsce problematyki etycznej i ekonomicznej w ekofilozofii, w: W. Tyburski (red.), Ekonomia, ekologia, etyka (materiały konferencyjne), Toruń, 7.

Dominik A., Semik A., 1988, Ekonomika wykorzystania zasobów naturalnych jako forma ochrony środowiska, Zeszyty naukowe Akademii Ekonomicznej im. Karola Adamieckiego w Katowicach, nr 112.

Dziadosz K., 2000, Racjonalność ekologiczna w prawie i polityce, Olsztyn.

Gałkowski T., 1998, Paradygmat odpowiedzialności za przyszłość $w$ etyce i prawie, w: R. Sobański (red.), Prawa człowieka w państwie ekologicznym, Warszawa, 211.

Górka K., Poskrobko B., Radecki W., 2001, Ochrona środowiska, Warszawa.

Górski M., 2009, Prawo ochrony środowiska, Warszawa.

Jan XXIII, 1981, Pacem in terris, w: Encykliki. Jan XXIII, Paweł VI, Jan Paweł II, Warszawa.

Jan Paweł II, 1981, Redemptor hominis, w: Encykliki. Jan XXIII, Paweł VI, Jan Paweł II, Warszawa.

Jan Paweł II, 1996a, Centesimus annus, w: Encykliki Ojca Świętego Jana Pawła II. T. II, Kraków.

Jan Paweł II, 1996b, Laborem exercens, w: Encykliki Ojca Świętego Jana Pawła II. T. I, Kraków.

Jan Paweł II, 1996c, Sollicitudo rei socialis, w: Encykliki Ojca Świętego Jana Pawła II. T. I, Kraków. Juros H., 1995, Natural Environment Protection vs. Redefinition of State, w: R. Sobański, S. Tafaro, W. Myszor, G. Dammacco, B. Sitek (eds.), I diritti fondamentali dell'uomo e dell'ambiente nei cambiamenti dell'Europa Centro-Orientale: atti del Congresso Internazionale, Warszawa.

Juros H., 1998, Ochrona środowiska naturalnego a redefinicja państwa, w: R. Sobański (red.), Prawa człowieka w państwie ekologicznym, Warszawa, 78. Kasprzak S. SVD, 2003, Normatywny wymiar ekologicznych $i$ sozologicznych idei w systemie prawa państwowego i kościelnego, Lublin.

Korzeniowski P., 2010, Zasady prawne ochrony środowiska, Łódź,

Kozłowski S., 1997, W drodze do ekorozwoju, Warszawa.

Krajewski P., 2008, Prawo do środowiska niezbywalnym prawem człowieka, Studia Prawnoustrojowe Uniwersytetu Warmińsko-Mazurskiego, nr 8.

Krajewski P., 2010, Ochrona prawna człowieka i jego środowiska wobec ekspansji organizmów genetycznie zmodyfikowanych w prawie wspólnotowym $i$ międzynarodowym, Olsztyn.

Kukułka J., 1992, Internacjonalizacja problemów ekologicznych a ksztattowanie tadu międzynarodowego E. J. Pałyga (red.), w: Ekologia społeczna i współpraca międzynarodowa w zakresie ochrony środowiska, Warszawa, s. 117.

Leszczyński L., Maroń G., 2013, Pojęcie i tressć zasad prawa oraz generalnych klauzul odsytajacych. Uwagi porównawcze, Annales UMCS Sectio G, vol. LX.

Lisicka H., 1998, Koncepcja zrównoważonego rozwoju podstawa polityki przemystowej i ochrony środowiska, Ochrona Środowiska. Prawo i Polityka, nr 1.

Lisicka H., Macek I., Radecki W., 1999, Leksykon ochrony środowiska. Prawo i polityka, Wrocław.

Łabno Z., 1987, Finansowe aspekty cywilnoprawnej ochrony środowiska (na przykładzie przepisów o ochronie powietrza atmosferycznego), Katowice. Łabno Z., 1988, Teologiczno-moralny problem ochrony środowiska a prawo, Śląskie Studia Historyczno-Teologiczne, $\mathrm{nr} 21$.

Łustacz L., 1975, Rola państwa i prawa w ochronie środowiska, w: Łustacz L. (red.), Prawo a ochrona środowiska, Wrocław - Warszawa - Kraków Gdańsk, s. 131-153.

Machowski J., 2000, Problemy prawne ochrony środowiska, Warszawa.

Machowski J., 2003, Ochrona środowiska. Prawo i zrównoważony rozwój, Warszawa. 
Malinowski M., 1996, Czym jest kultura?, w: A. Mencwel (red.), Wiedza o kulturze. Cz. I, Antropologia kultury. Zagadnienia i wybór tekstów, Warszawa.

Maśniak D., 2003, Ubezpieczenia ekologiczne, Kraków.

Mazur-Wierzbicka E., 2006, Miejsce zrównoważonego rozwoju w polskiej $i$ unijnej polityce ekologicznej na poczqtku XXI wieku, Nierówności społeczne a wzrost gospodarczy, nr 8.

Meadows D. H., Meadows D. L., Randers J., Behrens W. H. III, 1973, Granice wzrostu, przeł. W. Rączkowska, S. Rączkowski, Warszawa.

Menkes J., 1999, Prawo do środowiska jako prawo człowieka, w: A. Przyborowska-Klimczak (red.), Ekologia i prawo. Materiały sesji naukowej, Lublin, 7-8 czerwca 1997 r., Lubin, 35.

Muszyńska-Kurnik M, 2003, Europejska wspótpraca ekologiczna. Aspekty instytucjonalne i prawne, Warszawa.

Paweł VI, 1981, Populorum progressio, w: Encykliki. Jan XXIII, Paweł VI, Jan Paweł II, Warszawa.

Poskrobko B., 2005, Cykliczność, trwatość i równoważenie rozwoju, w: B. Poskrobko, S. Kozłowski (red.), Zrównoważony rozwój. Wybrane problemy teoretyczne i implementacja w świetle dokumentów Unii Europejskiej. Tom I Studia nad zrównoważonym rozwojem, Białystok - Warszawa, 19-35.

Przyborowska-Klimczak A., 2004, Ochrona przyrody. Studium prawno międzynarodowe, Lublin.

Równy K., 2000, Koncepcja zrównoważonego rozwoju w prawie wspólnotowym i polskiej rzeczywistości (Zarys najważniejszych zagadnień wyjściowych), Przegląd Prawa Europejskiego, nr 2, 58-71.
Rudnicki M., 2005, Prawnofinansowe aspektyzadań publicznych jednostek samorzadu terytorialnego zwiazanych $z$ ochrona środowiska, Lublin.

Rudnicki M., 2007, Zrównoważony rozwój jako podstawa polskiej polityki ekologicznej - w poszukiwaniu nowej formuty kompromisu ekologii z ekonomia, Studia Ecologiae et Bioethicae, tom 5, 209-224.

Semkow J., 1974, Społeczno-ekonomiczne aspekty ochrony środowiska, Studia Iuridica, nr 2.

Sobański R., 1998, Wprowadzenie, w: R. Sobański (red.), Prawa człowiek w państwie ekologicznym, Warszawa, 5.

Sobczak K., 1975, Problemy prawno administracyjne ochrony środowiska w rejonach uprzemystowionych, w: L. Łustacz (red.), Prawo a ochrona środowiska, Wrocław - Warszawa - Kraków - Gdańsk.

Voinov A., 2008, Understanding and communicating sustainability: global versus regional perspectives, Environment, development and sustainability, nr 10.

Wejroch J., 1972, Przyszłość ze znakami zapytania, Więź, nr 10, 33-45.

Wrzosek S., 1999, Zarzadzanie środowiskiem przez administracje publiczna $w$ Polsce, Białystok.

Życiński J., 1992, Ułaskawienie natury, Kraków.

A. Ustawa z dnia 27 kwietnia 2001 r. - Prawo ochrony środowiska (tekst jedn. Dz.U. 2013, poz. 1232 ze zm. z dnia 23 października 2013 r.) wyrok SN z dnia 3 lipca 1969 r., sygn. II CR 208/69, „OSPiKA” 1971, z. 5, poz. 87, s. 199

\section{Human in the socio-economic determinants of environmental protection}

\section{Summary}

In recent years, the issue of the position of human beings within their relationship with the environment takes on particular importance. Expression of this trend is for instance the gradual extension of the acquis that provides for certain symptoms of rights of individuals, the implementation of which is essential for achieving the objectives of environmental protection. It is therefore reasonable to attempt to consider the economic and axiological determinants of actions known as environmental protection. Hence the identification of anthropocentric basis and axiological sources of undertaken of the human environmental protection, are the subject of this study.

\section{Keywords}

human, environmental protection, axiology, business activity 